\title{
A Human Milk Factor Inhibits Binding of Human Immunodeficiency Virus to the CD4 Receptor
}

\author{
DAVID S. NEWBURG, RAPHAEL P. VISCIDI, ANDREA RUFF, AND ROBERT H. YOLKEN
}

\author{
Department of Biochemistry, E. K. Shriver Center, Waltham, Massachusetts 02254, and Department of \\ Neurology, Harvard Medical School, Boston, Massachusetts 02115 [D.S.N.]; Department of Pediatric Infectious \\ Diseases, Johns Hopkins School of Medicine, Baltimore, MD 21205 [R.P.V., R.H.Y.]; and Johns Hopkins School \\ of Hygiene and Public Health, Baltimore, Maryland 21205 [A.R.]
}

\begin{abstract}
Perinatal transmission of human immunodeficiency virus (HIV) from infected mothers to their children occurs at rates reported as $20-50 \%$. The role of breast feeding in perinatal transmission of viral infections has not been well established. We studied 34 milk and colostral samples obtained from HIV-seropositive and HIV-seronegative women to determine if they contained anti-HIV activity. We found that all the samples contained a factor that inhibited the binding of HIV epitope-specific MAb to recombinant $\mathrm{CD} 4$ receptor molecules. The titers of inhibitory activity ranged from 1:200 to $1: 10000$ and did not differ between HIV-seropositive and HIV-seronegative mothers. This milk factor also inhibited the binding of gp120 to CD4. Neither human sera nor bovine milk exhibited appreciable inhibitory activity. Fractionation of human milk indicated that the inhibitory activity was confined to the macromolecular fraction; little activity was found in isolated milk lipids or oligosaccharides. Chromatographic procedures indicated that the active macromolecule has an isoelectric point of 9.3-9.6. The active material did not bind to concanavalin $\mathrm{A}$; however, the activity was partially destroyed by chemical and enzymatic treatments that removed sulfated residues. The active material may thus be a sulfated protein, glycoprotein, mucin, or glycosaminoglycan that inhibits the binding of CD4 to HIV envelope glycoproteins. The role of this factor in the natural history of HIV infection in infants and children should be the subject of additional investigations. (Pediatr Res 31: 2228, 1992)
\end{abstract}

\section{Abbreviations}

HIV, human immunodeficiency virus aq., aqueous solution DEAE, diethylaminoethyl PAS, periodic acid Schiff reagent $\operatorname{sIgA}$, secretory IgA

Infants born to mothers infected with HIV are at high risk for HIV infection. The reported rates of vertical transmission from HIV-infected mothers range from 20 to $50 \%$ (1-5). A better

Received December 14, 1990; accepted August 19, 1991.

Reprint requests: David Newburg, E. K. Shriver Center, 200 Trapelo Road, Waltham, MA 02254

Supported by grants from the National Institute of Diabetes and Digestive and Kidney Diseases (1 RO1 DK40540), the National Institute of Child Health and Human Development (HD 13021), and the Massachusetts Department of Mental Retardation contract (3403-8403-306). understanding of the factors that influence disease transmission is essential to development of strategies to prevent AIDS transmission from HIV-infected mothers to their children.

Breast feeding is known to affect the transmission of viral infections from mother to child. Human milk contains a number of $\mathrm{Ig}$ and non-Ig factors that can inhibit the replication of pathogenic microbial agents (6-9). Conversely, human milk can contain viruses, such as cytomegalovirus and human T-cell leukemia virus, that can initiate neonatal infection (10-12); indeed, anecdotal reports have described the isolation of HIV from breast milk and the apparent infection of infants feeding on the milk of mothers who recently had sero-converted (13-15). The possible association between breast feeding and HIV transmission poses a medical dilemma, because breast-fed infants generally display lower rates of other infections than do infants fed bovine milk-based formula (16-20). The dilemma is particularly acute in the case of infants living in the less developed countries, because numerous studies have documented increased rates of infant mortality when bovine milk formula is substituted for human milk as the principal source of neonatal nutrition (2124). An improved understanding of factors in human milk that may modulate HIV infection might lead to the reassessment of the potential risks and benefits of breast feeding in populations with higher rates of maternal HIV infection.

Milk may modulate infection in neonates through several mechanisms. In addition to specific Ig and cell-mediated immune responses, human milk contains macromolecules that inhibit the binding of pathogenic agents to their host receptors. Such protective activity has been attributed to milk glycolipids (25) and oligosaccharides (26-28). The existence of analogous inhibitors of virus-receptor interactions could be of particular importance in the case of HIV infection, in light of the antigenic variation of neutralizing epitopes on the viral envelope and the relative conservation of the sites involved in receptor interactions (2931).

The CD4 molecule is the major receptor for HIV binding to T-helper lymphocytes and, possibly, to other cells that support HIV replication (32-34). Because the viral envelope is heavily glycosylated, it is likely that glycosyl groups on the envelope are important determinants of viral-cellular interactions, and that exogenous glycoconjugates can modulate HIV interaction with its receptor (35-40). The CD4 receptor molecule has been extensively characterized by means of its reactions with HIV envelope glycoprotein (gp120) and with MAb that bind at specific CD4 epitopes $(31,41,42)$, including the gp 120 binding site.

We used a solid-phase assay system to demonstrate that whole human milk inhibits the interaction of $\mathrm{CD} 4$ with MAb that bind at or near the site of HIV attachment and inhibits the binding of recombinant gp120 to CD4. We then purified milk samples, 
identified the active fraction by means of the same assay technique, and partially characterized the active material.

\section{MATERIALS AND METHODS}

Reagents. Purified recombinant CD4, cloned and expressed in Chinese hamster ovary cells, was kindly provided by Dr. R. Sweet, Smith Kline and French, King of Prussia, PA. Recombinant HIV envelope glycoprotein (gp120), cloned and expressed in baculovirus, was obtained from Smith Kline Biolabs, Van Nuys, CA. The methods used for the preparation and purification of these materials have been described $(43,44)$. OKT $4 A \mathrm{MAb}$ were purchased from Ortho Diagnostic Systems, Raritan, NJ. OKT4B, OKT4D, OKT4E, and OKT4F MAb were provided by Dr. Patricia Rao, RW Johnson Pharmaceutical Research Institute, Raritan, NJ. MT151 antibody was provided by Dr. Albert Luderer, Boehringer Mannheim Diagnostics, Indianapolis, IN. The 110-1 MAb to HIV gp 120 was obtained from Dr. Kathleen Shriver, Genetics Systems Corporation, Seattle, WA. The properties of these antibodies have been described $(34,45)$. Peroxidase-labeled goat anti-murine $\operatorname{IgG}$ and anti-murine $\operatorname{IgM}$ were purchased from Zymed Laboratories, South San Francisco, CA. Substituted dextrans and enzymes were obtained from Sigma Chemical Company, St. Louis, MO; other reagents were obtained from Fisher Scientific, Pittsburgh, PA, unless otherwise indicated.

Milk and Serum Samples. Milk samples from healthy, HIVseronegative mothers were obtained from the Central Massachusetts Regional Milk Bank, The Medical Center of Central Massachusetts, Worcester, MA, and samples represented a broad spectrum of human milk with regard to the stage of lactation, age of the mother, and parity. Serial samples during an $80-\mathrm{d}$ period were obtained from a healthy eastern Massachusetts $\mathrm{La}$ Leche League volunteer. Maryland samples were collected from healthy women who recently had delivered children at the Johns Hopkins Hospital in Baltimore. Milk samples also were obtained within $1 \mathrm{wk}$ postpartum from HIV-seropositive and HIV-seronegative mothers living in Cite Soleil, Haiti. Protocols and consent forms used during milk collection were approved by the Human Studies Committees of the respective parent institutions. All milk samples were stored at $-70^{\circ} \mathrm{C}$. Fresh, unprocessed bovine milk samples, obtained from cows from Maryland and Massachusetts, were immediately frozen and tested without additional processing. Pasteurized bovine milk was obtained commercially.

Serum samples were obtained from 23 HIV-seropositive and HIV-seronegative individuals residing in the Baltimore area.

CD4 Binding Assays. Recombinant CD4 was diluted to 0.25 $\mathrm{mg} / \mathrm{L}$ in $60 \mathrm{mmol} / \mathrm{L}$ carbonate buffer, $\mathrm{pH} 9.6$, and immobilized on wells of polyvinyl microtiter plates by incubation at $4^{\circ} \mathrm{C}$ for $14 \mathrm{~h}$. Unbound CD4 was cleared from the wells in an automated washer (Skatron Microwash I; Skatron, Inc., Sterling, VA) by five washes with PBST $(10 \mathrm{mmol} / \mathrm{L}$ phosphate buffer, $\mathrm{pH} 7.4$, in $150 \mathrm{mmol} / \mathrm{L} \mathrm{NaCl}$ containing $5 \mathrm{~g} / \mathrm{L}$ Tween 20 ).

A $100-\mu \mathrm{L}$ aliquot of the milk or milk fraction was incubated with an equal volume of OKT4A diluted 1:4000 in PBST. After incubation for $1 \mathrm{~h}$ at $37^{\circ} \mathrm{C}, 50-\mu \mathrm{L}$ aliquots were added to duplicate or triplicate wells coated with CD4 and an equal number of wells coated with buffer alone. After incubation for an additional $2 \mathrm{~h}$ at $37^{\circ} \mathrm{C}$, the wells were washed five times with PBST. The amount of bound MAb was quantified by reaction with peroxidase-labeled goat anti-mouse $\operatorname{IgG}$ and, after another washing step, by reaction with $\mathrm{H}_{2} \mathrm{O}_{2}$-o-phenylene diamine. The amount of color generated by the enzyme-substrate reaction was measured in a microplate colorimeter at $405 \mathrm{~nm}$. For each dilution of milk or of a milk fraction, a specific binding activity was calculated by subtracting the OD generated in the buffer-coated control well from that generated in the CD4-coated well. The specific binding activity was represented as a percentage according to the following formula:

$$
\left(1-\mathrm{SA}_{\mathrm{m}} / \mathrm{SA}_{\mathrm{b}}\right) \times 100
$$

where $\mathrm{SA}_{m}$ is the sp act of the milk fraction, and $\mathrm{SA}_{b}$ is the mean sp act of buffer control samples measured in the same microtiter plate. The inhibitory activity of the whole milk samples was calculated by testing the milk at several $\log _{10}$-fold dilutions and interpolating to the concentration that resulted in $50 \%$ inhibition of OKT4A-CD4 binding; this activity was expressed as $50 \%$ minimum inhibitory concentration.

In other experiments, CD4-reactive MAb were substituted for OKT4A. The OKT4B, OKT4D, OKT4E, OKT4F, and MT151 antibodies were diluted 1:4000, 1:2000, 1:400, 1:400, and 1:2000, respectively, and used as described above for OKT4A. These dilutions were selected to yield OD equivalent to that yielded by OKT4A in the absence of added inhibitor. OKT4B, which is an IgM-class antibody (34), was quantified by reaction with peroxidase-labeled anti-murine IgM, and the other MAb were measured by reaction with peroxidase-labeled anti-murine IgG. The percentage inhibition was calculated as for OKT4A.

Additional assays were performed in which gp 120 and monoclonal anti-gp120 antibody were substituted for the anti-CD4 antibodies. After dilution to a concentration of $4 \mathrm{mg} / \mathrm{L}$, gp 120 was incubated with an equal volume of milk fractions for 20 min at room temperature. The mixture was transferred to microtiter wells coated with CD4 or buffer, as described above, and incubated for $1 \mathrm{~h}$ at $37^{\circ} \mathrm{C}$. After washing, the amount of gp 120 bound to the CD4 was quantified by reaction with $110-1 \mathrm{MAb}$ antibody to gp120 and anti-murine $\operatorname{lgG}$. The percentage inhibition was calculated as described above for the OKT4A assay system.

Purification of Human Milk Fractions. Human milk oligosaccharide fractions. Previously frozen pooled human milk (1 L) was centrifuged at $4^{\circ} \mathrm{C}$ at $3000 \times g$ for $1 \mathrm{~h}$. The cream was removed, and the skimmed milk filtered through glass wool. The filtrate was mixed with an equal amount of ice-cold acetone, stirred overnight at $4^{\circ} \mathrm{C}$, and centrifuged at $3000 \times g$ for $45 \mathrm{~min}$ (46). The clear supernatant was reduced to approximately $0.2 \mathrm{~L}$ by rotary evaporation, and the resultant aqueous solution was applied to a 1-L charcoal-Celite column (charcoal: Norit decolorizing carbon and Celite 545; Fisher Scientific). After exhaustive washing with distilled water and $0.86 \mathrm{~mol} / \mathrm{L}$ ethanol (aq.), the oligosaccharide fraction was eluted from the column with $8.6 \mathrm{~mol} / \mathrm{L}$ ethanol (aq.). The eluate was passed through anion exchange resin $\mathrm{AG} 1-\mathrm{X} 2$ (formate) (BioRad, Richmond, $\mathrm{CA}$ ) to yield the neutral oligosaccharide fraction. The acidic oligosaccharides were eluted from the resin with $1 \mathrm{~mol} / \mathrm{L}$ formic acid (27). This procedure yielded approximately $6 \mathrm{~g}$ of neutral fraction and $18 \mathrm{mg}$ of acidic oligosaccharide.

Human milk lipid fractions. Milk was extracted with 20 volumes of chloroform/methanol (2:1), filtered, and dried. The lipid was then partitioned between hexane and $15 \mathrm{~mol} / \mathrm{L}$ aqueous ethanol. FFA were removed from the hexane fraction by washing with methanolic ammonia, and the fatty acids were recovered by acidifying the methanol and extracting the protonated fatty acids with hexane. The ethanol fraction was subjected to Folch partition; the upper phase lipids were isolated on a reversedphase column and then separated on DEAE Sepharose (Pharmacia, Uppsala, Sweden) into the neutral glycolipids and the anionic glycolipids (the ganglioside fraction) (47). The Folch lower phase lipids were separated on a Unisil silicic acid column (Clarkson Chemical, Williamsport, PA) into the residual nonpolar lipid fraction, the lower phase glycolipid fraction, and the phospholipid fraction (48).

Human milk protein fractions. Protein (or macromolecular) fractions were prepared as outlined in Figure 1: cream was separated from the milk by centrifugation at $3000 \times g$ for $1 \mathrm{~h}$ at $4^{\circ} \mathrm{C}$ and removed by filtration through glass wool. The resulting skimmed milk was passed through a $0.45-\mu \mathrm{m}$ filter; the filtrate and retentate were passed separately through a $10000-\mathrm{D}$ cutoff ultrafilter, and the retentates were washed three times with 


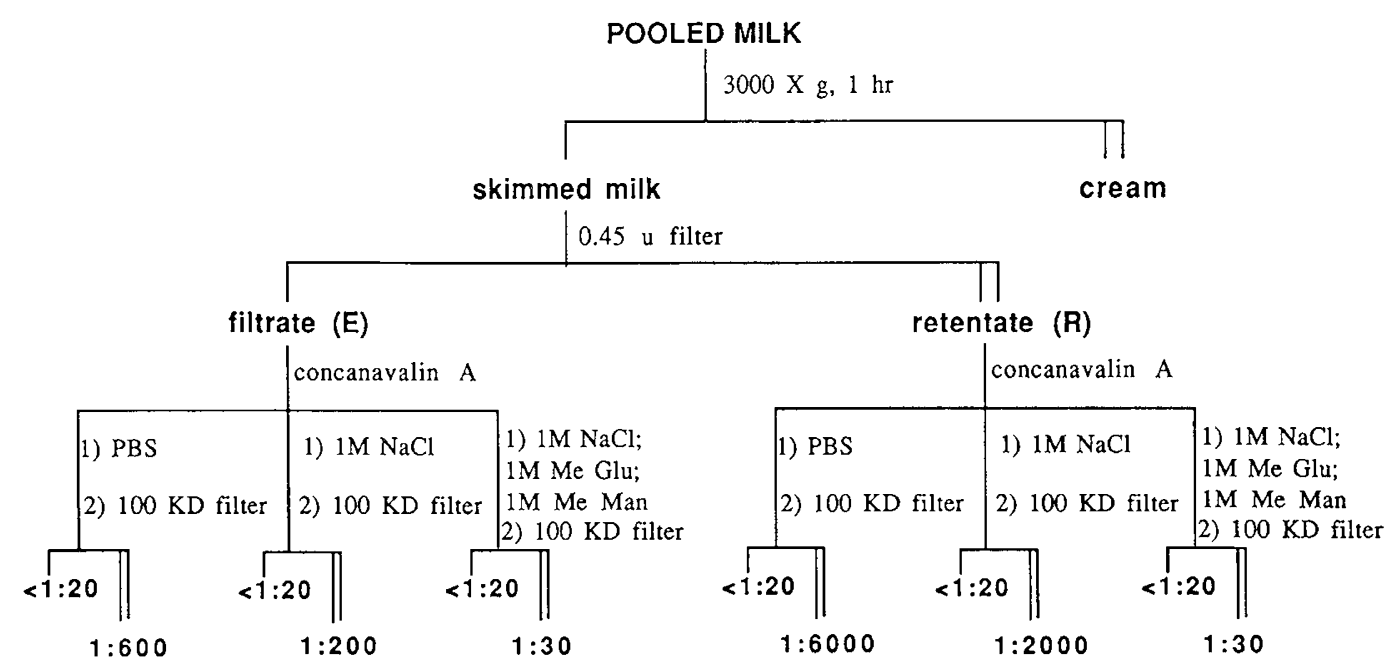

Fig. 1. Milk protein fractionation. A pooled milk sample from HIV-seronegative women was centrifuged to remove the cream. The skimmed milk was clarified through a $0.45-\mu \mathrm{m}$ filter. Both the filtrate and retentate were subjected to diafiltration with a $10000-\mathrm{D}$ cutoff ultrafilter; the retentates were passed through a concanavalin A lectin affinity column. All fractions were subjected to the CD4 inhibitory activity assay. The dilution yielding 50\% inhibition is depicted under the double vertical lines. The values under the single vertical lines (all $<1: 20)$ indicate the absence of inhibitory activity in the low molecular weight $(<100000-\mathrm{D})$ portions of each fraction.

distilled water (diafiltration). Each of the retentates was then lyophilized and weighed.

Seven hundred and fifty mg of each of these protein fractions was purified through a $0.04-\mathrm{L}$ concanavalin A-sepharose affinity column. The column was washed with $0.2 \mathrm{~L}$ of PBS $(10 \mathrm{mmol} /$ $\left.\mathrm{L} \mathrm{NaH} \mathrm{PO}_{4}, 100 \mathrm{mmol} / \mathrm{L} \mathrm{NaCl}, \mathrm{pH} 7.0\right) ; 0.2 \mathrm{~L}$ of buffered 1 $\mathrm{mol} / \mathrm{L} \mathrm{NaCl}$; and $0.2 \mathrm{~L}$ of a solution containing $1 \mathrm{~mol} / \mathrm{L}$ methyl glucoside, $1 \mathrm{~mol} / \mathrm{L}$ methyl mannoside, and $1 \mathrm{~mol} / \mathrm{L} \mathrm{NaCl}, \mathrm{pH}$ 7.0. All fractions were subjected to diafiltration using a 100000 D membrane (Amicon, Danvers, MA) followed by dialysis and lyophilization.

Chromatographic Separations. The protein fraction with the highest activity was further purified through a Sephadex G-200 $\mathrm{SF}$ molecular sieving column. A total of $288 \mathrm{mg}$ of sample, dissolved in running buffer $(10 \mathrm{mmol} / \mathrm{L}$ Tris, $100 \mathrm{mmol} / \mathrm{L} \mathrm{NaCl}$, $250 \mathrm{mmol} / \mathrm{L}$ EDTA), was applied to a column with a void volume of $0.75 \mathrm{~L}$, and the material was chromatographed at a flow rate of $0.04 \mathrm{~L} / \mathrm{h}$. Three major peaks, one of which was the void volume, and several minor peaks appeared when the absorbance of the column effluent was measured at $280 \mathrm{~nm}$.

The active protein fraction was also analyzed by means of ion exchange chromatography. A $1-\mathrm{mL}$ aliquot was dissolved in buffer, pH 7.4, and the sample was applied to a $2-\mathrm{mL}$ column of DEAE-Sephacryl. Fractions were eluted by means of a stepwise gradient of increasing concentrations of $\mathrm{NaCl}, \mathrm{pH} 7.4$. The resulting eluates were tested for activity by the CD4-OKT4A inhibition assay.

Isoelectric Focusing. The protein fraction of another $0.15-\mathrm{L}$ sample of pooled human milk was prepared as above: the cream was removed by centrifugation, and the macromolecular (protein) fraction was isolated from the skimmed milk by diafiltration through a $10000-\mathrm{D}$ ultrafilter. This protein fraction was separated by high-resolution preparative isoelectric focusing in a Rotofor apparatus (BioRad). The protein fraction was made 10 $\mathrm{g} / \mathrm{L}$ with ampholytes ( $\mathrm{pH} 3-10$ ) in $0.05 \mathrm{~L}$ distilled water and was resolved at $16 \mathrm{~W}$ for $4 \mathrm{~h}$. The 20 resulting fractions each represented isoelectric points of between 3 and 10 . After dialysis and lyophilization, these fractions also were tested for their ability to inhibit CD4 binding.

$P A G E$. The 20 fractions described above from the Rotofor apparatus were reduced and denatured in the presence of SDS, and the components were resolved by electrophoresis through a $4-12 \%$ polyacrylamide gel slab in a discontinuous gradient (49). The resolved bands were visualized with silver stain (New Eng- land Nuclear, Boston, MA), and the carbohydrate-containing material was detected with PAS (50).

Free Soluble CD4 Levels. We performed assays to determine levels of free CD4 in the milk samples. The OKT4B IgM MAb was diluted 1:800 and bound to the wells of the microtiter plate overnight at $4^{\circ} \mathrm{C}$. After the wells were washed, the milk samples were added and incubated for $1 \mathrm{~h}$ at $37^{\circ} \mathrm{C}$. The amounts of CD4 were determined by subsequent reactions with the OKT4A IgG $\mathrm{MAb}$, peroxidase-labeled anti-murine $\mathrm{IgG}$, and enzyme substrate, as described above. A set of standards consisting of known concentrations of recombinant CD4 was run in each assay.

Enzymatic Treatments. Aliquots of the active macromolecular fractions, which had been passed through a $0.45-\mu \mathrm{m}$ filter and purified by ultrafiltration and dialysis as outlined above, were subjected to enzymatic digestion. The equivalent of $1 \mathrm{~mL}$ of milk (6.7 mg of macromolecular fraction) was dissolved in $1 \mathrm{~mL}$ of buffer containing $50 \mu \mathrm{g}$ gentamicin sulfate and incubated with enzyme for $50 \mathrm{~h}$. Digestion with neuraminidase from Vibrio cholera (0.05 U; Calbiochem, La Jolla, CA) was in water containing $1 \mathrm{mmol} / \mathrm{L} \mathrm{CaCl}$. Digestion with sulfatase from Patella vulgata (limpet) was in $0.05 \mathrm{~mol} / \mathrm{L}$ acetate buffer, $\mathrm{pH} 5.0$, at a concentration of $0.5 \mathrm{~g}(5000 \mathrm{U}) / \mathrm{L}$. One unit of sulfatase from Aerobacter aerogenes was buffered with $0.05 \mathrm{~mol} / \mathrm{L}$ Tris, $\mathrm{pH} 7.5$. Sulfatase from abalone entrails was used at a concentration of $10000 \mathrm{U} / \mathrm{L}$ of $0.05 \mathrm{~mol} / \mathrm{L}$ acetate buffer. Each digested sample was tested for CD4 binding inhibition. For each enzymatic digestion, a blank sample containing only buffer and enzyme was tested to assess the effect of residual enzymatic activity on CD4-OKT4A binding.

Chemical Treatments. The chemical stability of the active milk factor was tested. Aliquots were subjected to $80^{\circ} \mathrm{C}$ distilled deionized water for $3 \mathrm{~h}$, methanol at ambient temperature for $24 \mathrm{~h}$ (with and without $60 \mathrm{mmol} / \mathrm{L}$ ammonium acetate), or reductive alkylation [ $3 \mathrm{mg}$ protein in $1 \mathrm{~mL}$ Tris buffer $(1 \mathrm{~mol} /$ $\mathrm{L}, \mathrm{pH} 7.5), 10 \mathrm{~g} / \mathrm{L} \mathrm{SDS}$ ] with $450 \mu \mathrm{g}$ DTT at $37^{\circ} \mathrm{C}$ for $4 \mathrm{~h}$ followed by $5 \mathrm{mg}$ iodoacetamide at $37^{\circ} \mathrm{C}$ for $2 \mathrm{~h}$. After dialysis and lyophilization, these fractions were tested for changes in CD4 binding inhibition.

\section{RESULTS}

All of the milk samples obtained from women living in Massachusetts, Maryland, and Haiti inhibited binding of CD4 to the OKT4A MAb (Fig. 2). The geometric mean titer of inhibitory activity was $1: 1610$ (95\% confidence intervals, 1:1160-1:2220). 


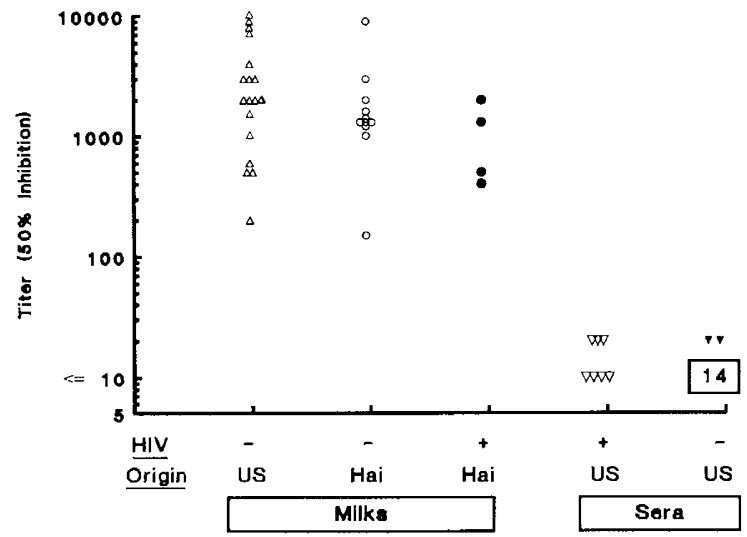

Fig. 2. CD4 inhibitory activity of individual human milk and sera specimens. Milk samples were from women living in Massachusetts and Cite Soleil, Haiti; sera were from HIV-seropositive and HIV-seronegative adults living in Baltimore, Maryland. Blocking activity was measured in the CD4-OKT4A inhibition assay. The box indicates that $14 \mathrm{HIV}$ positive samples had inhibition titers $\leq 1: 20$.

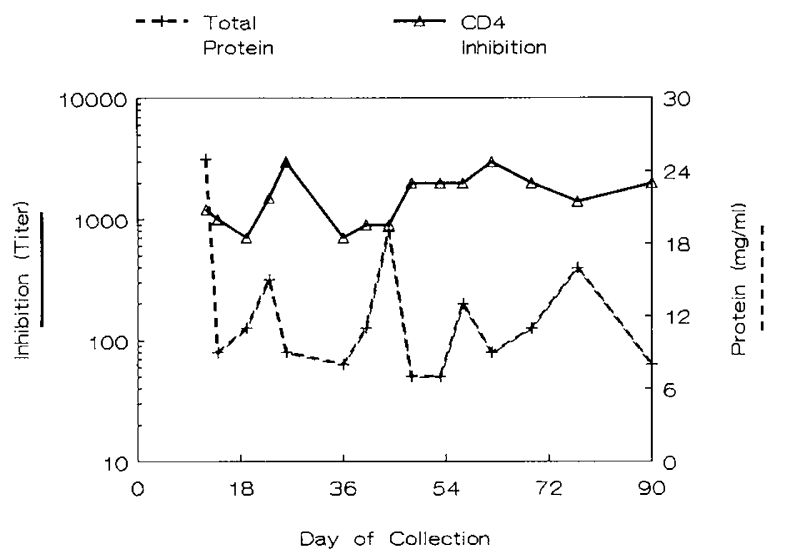

Fig. 3. CD4 inhibitory activity of serial milk samples obtained from an HIV-seronegative woman. Samples obtained on d 281-360 postgestation were stored at $-70^{\circ} \mathrm{C}$ until assayed for CD4-OKT4A inhibition. Total protein was measured by the method of Lowry.

No significant differences in the levels of inhibitory activity were measured among the different populations (51).

Similarly, serial samples obtained from a Massachusetts woman whose lactation was mature and well established displayed consistent inhibitory activity over an 80 -d period, with titers ranging from 1:700 to 1:3000, despite variation in the level of total protein (Fig. 3).

In contrast to the universal presence of high levels of inhibitory activity in human milk, levels of inhibitory activity in sera were 1:20 or lower (Fig. 2). Similarly, inhibitory activity was not detected in raw or pasteurized bovine milk preparations. We found that dextran sulfate displayed inhibitory activity in this assay system at concentrations as low as $1 \mathrm{mg} / \mathrm{L}$. Inhibitory activity was not found with diethylamino-dextran or unsubstituted dextrans at concentrations as high as $100 \mathrm{mg} / \mathrm{L}$ (Fig. 4).

To identify the active component of human milk, we tested the inhibitory activity of isolated oligosaccharide, lipid, and protein fractions (Fig. 4). No inhibitory activity was found in the oligosaccharide fractions, and only low levels were found in the lipid fractions. However, the protein fractions (containing all macromolecules including mucins and glycosaminoglycans) displayed high titers of inhibitory activity. Most of the activity was retained by a $0.45-\mu \mathrm{m}$ filter, although measurable activity was found in the filtrate.

When this mixture of milk macromolecules was further fractionated by means of ultrafiltration and concanavalin A affinity

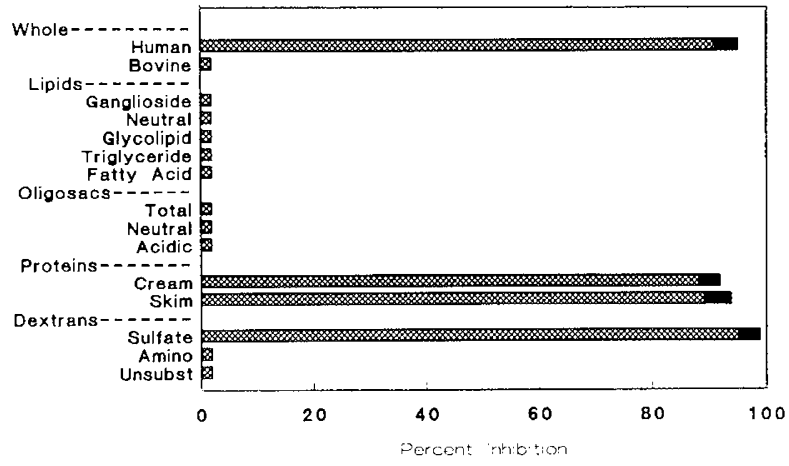

Fig. 4. CD4-OKT4A inhibitory activity of milk fractions. Pooled human milk was fractionated as outlined in Materials and Methods and tested for inhibitory activity in the CD4-OKT4A assay. Values are expressed as the mean percentage inhibition produced by each fraction $\pm 1 \mathrm{SD}$.

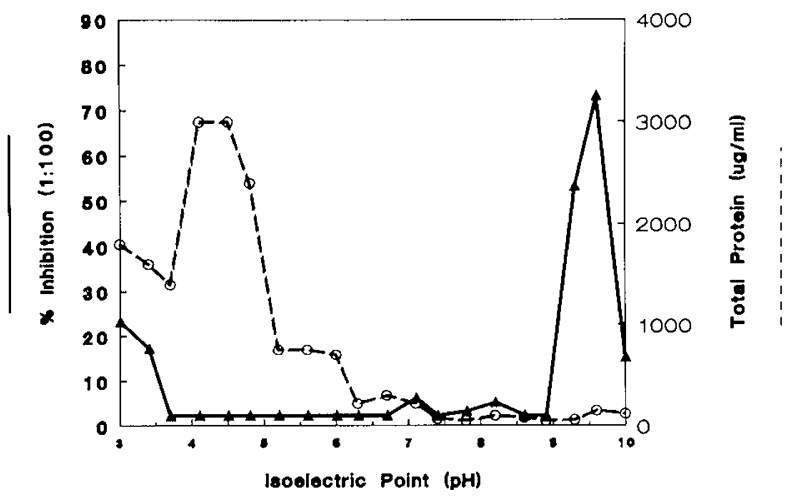

Fig. 5. Isoelectric focusing of human milk macromolecules. Pooled human milk protein was separated into 20 subfractions by preparative isoelectric focusing at $16 \mathrm{~W}$ for $4-5 \mathrm{~h}$ using a Rotofor apparatus. Each fraction was tested for total protein, using a commercially available assay (BioRad), and for CD4 inhibitory activity.

chromatography (Fig. 1), the highest activity in both the filtrate and retentate subfractions of $0.45-\mu \mathrm{m}$ filtration was associated with the initial column eluate. Little of the active material specifically bound to concanavalin A.

The most active macromolecular fraction was applied to a Sephadex G200 SF molecular sieving column. The CD4-OKT4A inhibitory activity was found largely in the void volume, indicating that the active material has a molecular weight above 250000 $\mathrm{D}$ under the native conditions used for the chromatography. Ion exchange chromatography performed with DEAE-Sephacryl indicated that most of the activity eluted between 0.2 and $0.3 \mathrm{~mol} /$ $\mathrm{L} \mathrm{NaCl}$ (aq.) (data not shown).

The pooled milk protein fraction was separated by preparative isoelectric focusing into 20 subfractions, which differed by their isoelectric points. Most of the CD4 inhibitory activity was found in fractions whose constituents had isoelectric points ranging from 9.3 to 9.6 (Fig. 5). The bulk of the milk protein fraction, however, migrated to subfractions which were substantially more acidic. Thus, the sp act of the active fractions was 300 -fold greater than that of the original milk protein preparation.

When these 20 subfractions were resolved by PAGE (Fig. 6), four major bands seemed to characterize the two most active fractions (lanes 18 and 19 from the left). The three bands with the highest apparent molecular weights stained positively for carbohydrate by PAS. At the top of the gel, the faint bands by silver stain were more strongly stained with PAS and showed two diffuse bands similar to those produced by the human milk mucins associated with the milk fat globule membrane.

The active fraction of the concanavalin A column separation was also characterized by means of enzymatic digestion. As 


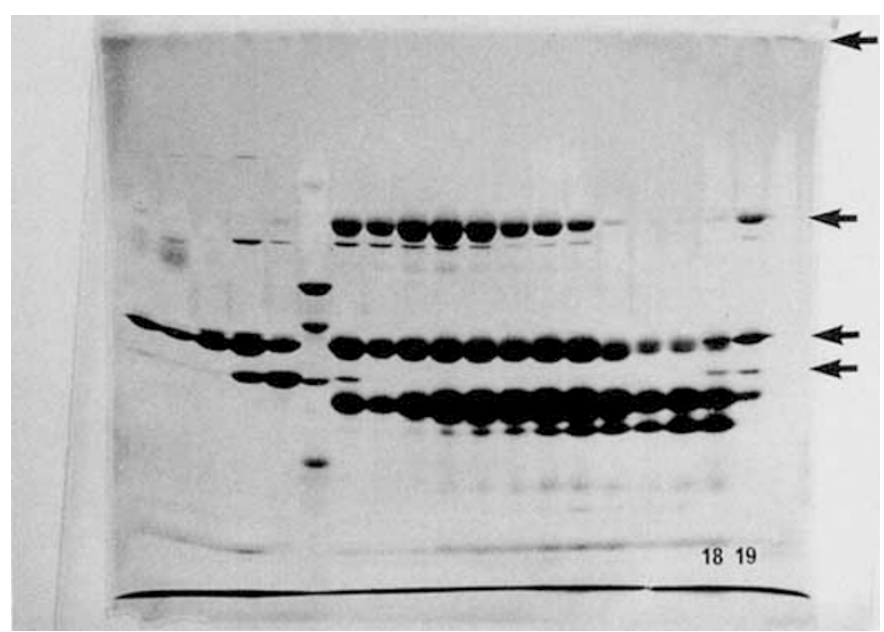

Fig. 6. PAGE of fractions separated by isoelectric focusing. A $100-\mu \mathrm{g}$ aliquot of each of the 20 fractions from isoelectric focusing (Fig. 5) was applied to a $4-12 \%$ gradient polyacrylamide slab and resolved by electrophoresis. Only $50 \mu \mathrm{g}$ of material was available for lane 18 (from the left) and, in place of fraction 6 , molecular weight markers were run to include 200,116, 97, 66, and $45 \mathrm{kD}$. Lanes 18 and 19 contained most of the CD4 blocking activity; the top three bands appear to be specific to these fractions. A fourth, more diffuse band seen at the top of lanes 18 and 19 is consistent with published reports on the electrophoretic behavior of milk mucins. PAS stained the diffuse band as well as the top two major bands of these lanes, indicating that these are glycosylated.

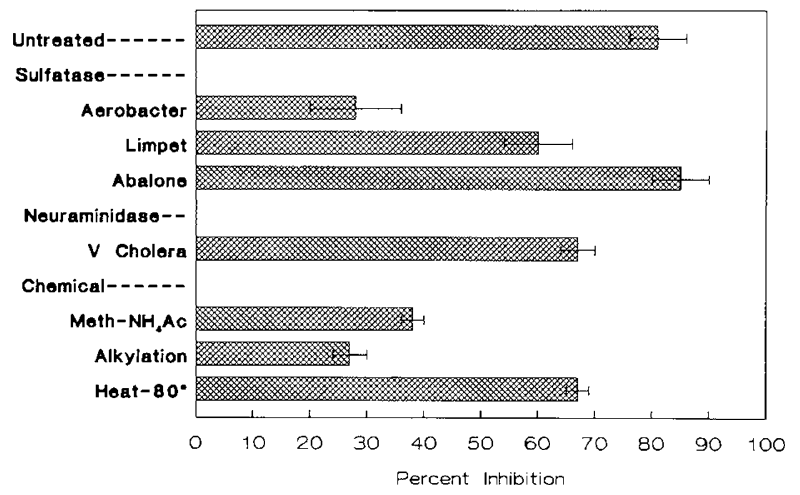

Fig. 7. Effect of enzymatic and chemical treatments on CD4 inhit -tory activity. Pooled human milk macromolecular fractions were digested with sulfatases or neuraminidase or treated with methanol, heat, or reductive alkylation, followed by the assay for CD4 blocking activity. Values represent mean \pm 1 SD of the percentage of inhibition.

depicted in Figure 7, the activity was not affected by treatment with neuraminidase from $V$. cholerae. However, treatment with sulfatase from $A$. aerogenes resulted in a substantial reduction of OKT4A-CD4 inhibitory activity. Treatment with sulfatase from $P$. vulgata (limpet) caused a less striking decrease of inhibitory activity, and sulfatase from abalone entrails caused no appreciable change in activity. These enzymes did not by themselves affect CD4-OKT4A binding.

The inhibitory activity of the active fraction was greatly reduced by treatment with methanol, methanolic-HCl, or with methanol buffered with ammonium acetate. Reductive alkylation also resulted in an appreciable loss of activity. Heating in water at $80^{\circ} \mathrm{C}$ for $3 \mathrm{~h}$, in contrast, reduced inhibitory activity only slightly.

Other MAb whose epitopes are found within the HIV binding site of the CD4 molecule were used to test the CD4 binding inhibition by the macromolecular fraction. As shown in Figure 8 , the binding of CD4 to OKT4D, OKT4E, and MT151 MAb was inhibited to the same extent as the binding to OKT4A had

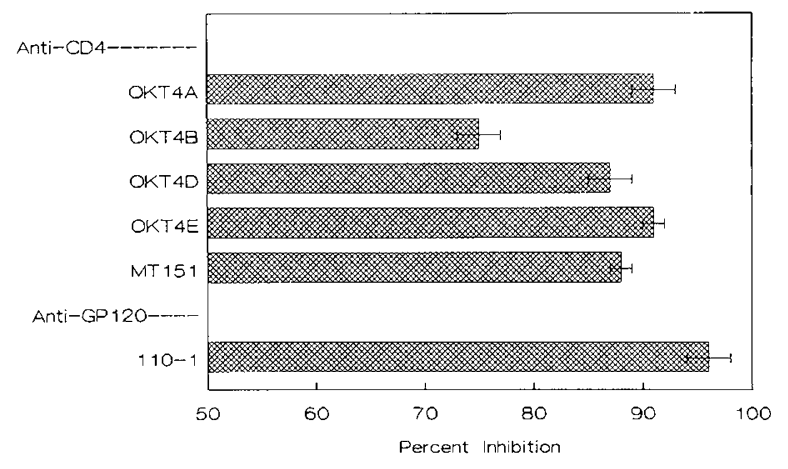

Fig. 8. Comparison of the ability of MAb and gp 120 to detect CD4 blocking activity of the active human milk factor. Human milk protein fraction was diluted 1:100 in PBS, pH 7.4, and its effect on the binding of CD4 to HIV-1 gp 120 and the indicated MAb was measured. Values represent mean \pm 1 SD percentage of inhibition.

been. Binding to the OKT4B MAb was inhibited to a somewhat lesser extent. (OKT4 and OKT4F MAb did not display reproducible binding to CD4 in our assay system.) The active fraction inhibited the binding of CD4 to a recombinant HIV envelope protein as well; bound envelope protein was detected by means of a MAb directed at a gp 120 epitope located outside of the CD4 binding domain.

Assays to determine the level of free soluble CD4 in the breast milk samples indicated that none of the tested milks or active milk fractions contained detectable levels of free CD4 above the detection limit of $1 \mathrm{ng} / \mathrm{mL}$. Any ligand-bound CD4 would not be detected in this assay, but bound CD4 in milk is less likely to competitively inhibit binding to the CD4 immobilized on a solid phase assay. Thus, CD4 in milk does not seem to be responsible for the CD4 blocking activity of human milk.

Studies of CD4 binding inhibition by milk were performed in which the solid-phase bound CD4 was incubated with milk and washed, and then inhibition of ligand binding to CD4 was measured. Because this sequence gave the same inhibition as when ligand and milk are incubated simultaneously with solidphase bound CD4, we concluded that the inhibitor of CD4 binding in human milk was acting by binding to CD4 and not to its ligands.

\section{DISCUSSION}

The binding of gp120, the outer coat protein of HIV, to CD4, the receptor molecule in the host cell, is thought to be a critical first step in the infection process. Our studies indicate that human milk contains high levels of a material that inhibits the interaction of CD4 with MAb that recognize HIV epitopes. This material also inhibits the binding of purified gp120 to CD4. The highly conserved nature of the portions of gp120 involved in CD4 binding suggests that this inhibitory activity may affect many strains of HIV-1 and HIV-2 (29). Indeed, the effect of the milk CD4 inhibitory activity on the replication of different strains of HIV should be the subject of additional investigations.

The inhibitory material seems to be widespread, as it was found in milk specimens from geographically and ethnically diverse populations, and was consistently present in milk samples representing a prolonged period of lactation. The absence of inhibition by bovine and several other milks (data not shown) suggests that the inhibitory activity is not due to a nonspecific effect of milk, but rather to a specific interaction with human CD4 molecules.

We were able to document that the blocking effect was not due to the presence of free soluble CD4, inasmuch as we could not detect CD4 antigen directly in the milk specimens. Our assay would not have detected bound CD4 in milk, thus the issue of whether some soluble CD4 exists in milk bound to the blocking agent has not been addressed directly; however, ligand-bound 
CD4 would not be expected to contribute toward blocking CD4 binding on the solid phase assay. On the basis of the current data, any soluble CD4, if present at all, is present in lesser amounts than the blocking factor of milk, and we would postulate that its presence would only diminish the blocking effect. Furthermore, the physical and chemical properties of the blocking macromolecule in milk are different from those of CD4 with regard to molecular weight, isoelectric point, and possibly sulfation. Finally, if soluble CD4 were the blocking agent of milk, one would expect its mechanism of action to involve competitive binding with the ligands rather than to the immobilized CD4. When immobilized CD4 is exposed to milk and washed before exposure to its ligand, the block in binding is comparable to that resulting from coincubation of milk and ligand with the CD4. This implies that the blocking factor acts by binding to CD4, arguing further against milk CD4 as the active agent.

The active fraction of human milk was partially characterized. The activity is largely confined to the macromolecular fraction. Chromatographic analysis indicated that the active material is a macromolecule with negatively charged regions, but has an isoelectric point in the 9.3-9.6 range. The presence of acidic regions within a large molecule whose overall charge is basic could account for these properties. Enzymatic analysis indicated resistance to trypsin, but sensitivity to sulfatase from $A$. aerogenes and, to a lesser extent, to limpet sulfatase. The results of these analyses indicate that the active material may be a sulfated macromolecule. This finding is of interest in light of the recognized inhibitory activity of dextran sulfate and other sulfated glycoproteins on the binding of HIV to CD4 and on the cellular replication of HIV virions (52). A milk fraction was isolated by preparative isoelectric focusing whose specific activity was $300-$ fold higher than the parent macromolecular preparation. Its $\mathrm{sp}$ act was an order of magnitude greater than that of dextran sulfate. Inasmuch as this fraction contained several major constituents, the sp act of the inhibitor of gp 120/CD4 binding from milk may be much more than an order of magnitude greater than that of dextran sulfate, implying that it may involve a more specific mechanism of blocking.

Because this factor is found in the milk of both seropositive and seronegative mothers, the effect cannot be attributed to specific SIgA against HIV epitopes. Other data indicate that the blocking factor is not related in a nonspecific manner to the SIgA fraction: Unlike sIgA, the blocking factor is found to have a tendency to aggregate and does not show affinity to concanavalin A; furthermore, the peak activity of the blocking factor occurs in fractions containing little of the total sIgA. Purified milk mucin fractions, essentially free of antibody, also inhibit CD4 binding (data not shown).

The most striking physical-chemical property of the active milk protein is its high isoelectric point, a property that contrasts with the acidic nature of lactalbumin, lactoglobulin, and other milk proteins (53). Such characteristics, including the stability of the protein to heat denaturation in water, its sensitivity to methanol denaturation at ambient temperatures, and its tendency to aggregate and be retained in a $0.45-\mu \mathrm{m}$ filter, are consistent with the characteristics of a family of macromolecules with hydrophobic domains (54-56), such as those found in membrane-associated proteins. The active material in human milk may thus prove to be a sulfated membrane glycoprotein, proteoglycan, or mucin whose binding to CD4 prevents the attachment of HIV envelope glycoprotein. Human milk fat globule mucins, when analyzed by PAGE, display characteristics similar to those displayed by the highest-molecular-weight band of the active fractions. The material could also be a glycosaminoglycan that associates with a membrane protein. The identification and further purification of the active milk constituent(s), and the elucidation of its mechanism of action, should be the subject of additional investigations.

A similar activity has recently been described in human saliva (57). This distribution of inhibitory activities in human milk and saliva, but not in sera, may relate to the epidemiology of HIV infection: a high rate of transmission by parenteral exposure is observed, in contrast to the relatively low rate of transmission by fecal-oral contact.

Numerous studies have indicated a protective effect of breast feeding on infant morbidity and mortality, especially in children living in less developed countries (16-24). However, the role of breast feeding in the management of children born to HIVinfected mothers remains controversial, in light of anecdotal reports of apparent postnatal HIV transmission from mothers to breast-fed children and of the rare isolation of HIV from human milk (13-15). The findings reported herein raise questions on whether human milk is an efficient agent for the vertical transmission of HIV. Thus, the role of breast feeding in the health of HIV-infected children and in the natural history of perinatal HIV infection requires further study.

Acknowledgments. The authors thank Dr. Frank Oski for his thoughtful suggestions and Louise Kittredge for her editing of the manuscript.

\section{REFERENCES}

1. Rogers MF, Ou CY, Rayfield M, Thomas PA, Schoenbaum EE, Abrams E, Krasinski K, Selwyn PA, Moore J, Kaul A, Grimm KT, Bamji M, Schochetman G, New York City Collaborative Study of Maternal HIV Transmission, Montefiore Medical Center HIV Perinatal Transmission Study Group 1989 Use of the polymerase chain reaction for early detection of the proviral sequences of human immunodeficiency virus in infants born to seropositive mothers. N Engl J Med 320:1649-1654

2. Strauss J, Abitbol C, Zilleruelo G, Scott G, Paredes A, Malaga S, Montane B, Mitchell C, Parks W, Pardo V 1989 Renal disease in children with the acquired immunodeficiency syndrome. N Engl J Med 321:625-630

3. Lifson AR, Rogers MF 1986 Vertical transmission of human immunodeficiency virus. Lancet 2:337

4. Rubinstein A, Bernstein LJ 1986 The epidemiology of pediatric acquired immunodeficiency syndrome. Clin Immunol Immunopathol 40:115-121

5. Ryder RW, Nsa W, Hassigs E, Behets F, Rayfield M, Ekungola B, Nelson AM Mulenda U, Francis H, Mwandagalirwa K, Davachi F, Rogers M, Nzilambi N, Greenberg A, Mann J, Quinn TC, Piot P, Curran JW 1989 Perinatal transmission of the human immunodeficiency virus type 1 to infants of seropositive women in Zaire. N Engl J Med 320:1637-1642

6. Yolken RH, Wyatt RG, Mata L, Urrutia JJ, Garciá B, Chanock RM, Kapikian AZ 1978 Secretory antibody directed against rotavirus in human milk: measurement by means of enzyme-linked immunosorbent assay. J Pediatr 93:916-921

7. Thormar H, Isaacs CE, Brown HR, Barshatzky MR, Pessolano T 1987 Inactivation of enveloped viruses and killing of cells by fatty acids and monoglycerides. Antimicrob Agents Chemother 31:27-31

8. Toms GL, Gardner PS, Pullan CR, Scott M, Taylor C 1980 Secretion of respiratory syncytial virus inhibitors and antibody in human milk throughout lactation. J Med Virol 5:351-360

9. Faden H, Ogra PL 1981 Breast milk as an immunologic vehicle for transport of immunocompetence. In: Lebenthal E (ed) Textbook of Gastroenterology and Nutrition in Infancy. Raven Press, New York, pp 355-364

10. Ando $Y$, Nakano S, Saito K, Shimamoto I, Ichijo M, Toyama T, Hinuma $Y$ 1987 Transmission of adult T-cell leukemia retrovirus (HTLV-I) from mother to child: comparison of bottle- with breast-fed babies. Jpn $J$ Cancer Res 78:322-324

11. Kinoshita K, Yamanouchi K, Ikeda S, Momita S, Amagasaki T Soda H Ichimaru M, Moriuchi R, Katamine S, Miyamoto T, Hino S 1985 Oral infection of a common marmoset with human T-cell leukemia virus type-I (HTLV-I) by inoculating fresh human milk of HTLV-I carrier mothers. Jpn J Cancer Res 76:1147-1153

12. Dworsky M, Yow M, Stagno S, Pass RF, Alford C 1983 Cytomegalovirus infection of breast milk and transmission in infancy. Pediatrics 72:295-299

13. Thiry L, Sprecher-Goldberger S, Jonckheer $T$, Levy J, Van de Perre P, Henrivaux P, Cogniaux-LeClerc J, Clumeck N 1985 Isolation of AIDS virus from cell-free breast milk of three healthy virus carriers. Lancet 2:891-892

14. Lepage $P$, Van de Perre $P$, Carael M, Nsengumuremyi F, Nkurunziza J, Butzler JP, Sprecher S 1987 Postnatal transmission of HIV from mother to child. Lancet 2:400

15. Zeigler JB, Cooper DA, Johnson RO, Gold J 1985 Postnatal transmission of AIDS-associated retrovirus from mother to infant. Lancet 1:896-898

16. Fallot ME, Boyd III JL, Oski FA 1980 Breast-feeding reduces incidence of hospital admissions for infection in infants. Pediatrics 65:1121-1124

17. Downham MA, Scott R, Sims DG, Webb JKG, Gardner PS 1976 Breastfeeding protects against respiratory syncytial virus infections. $\mathrm{Br}$ Med $\mathrm{J}$ 2:274-276

18. Schaefer O 1971 Otitis media and bottle-feeding. An epidemiological study of infant feeding habits and incidence of recurrent and chronic middle ear discase in Canadian Eskimos. Can J Public Health 62:478-489 
19. France GL, Marmer DJ, Steele RW 1980 Breast-feeding and Salmonella infection. Am J Dis Child 134:147-152

20. Grulee CG, Sanford HN, Schwartz H 1935 Breast and artificially fed infants; study of the age incidence in the morbidity and mortality in 20,000 cases. JAMA 104:1986-1988

21. Plank SJ, Milanesi ML 1973 Infant feeding and infant mortality in rural Chile. Bull WHO 48:203-210

22. Cunningham AS 1977 I. Morbidity in breast-fed and artificially fed infants. J Pediatr 90:726-729

23. Cunningham AS 1979 II. Morbidity in breast-fed and artificially fed infants. J Pediatr 94:685-689

24. Cussen GH 1980 Breast feeding and infant mortality. In: Wharton B (ed) Topics in Perinatal Medicine. Pitman Medical, Kent, England, pp 79-87

25. Otnaess AB, Laegreid A, Ertresvag K 1983 Inhibition of enterotoxin from Escherichia coli and Vibrio cholerae by gangliosides from human milk. Infect Immunol 40:563-569

26. Cleary TG, Chambers JP, Pickering LK 1983 Protection of suckling mice from the heat-stable enterotoxin of Escherichia coli by human milk. J Infect Dis 148:1114-1119

27. Newburg DS, Pickering LK, McCluer RH, Cleary TG 1990 Fucosylated oligosaccharides of human milk protect suckling mice from heat-stabile enterotoxin of Escherichia coli. J Infect Dis 162:1075-1080

28. Andersson B, Porras O, Hanson LA, Lagergard T, Svanborg-Eden C 1986 Inhibition of attachment of Streptococcus pneumoniae and Haemophilus influenzae by human milk and receptor oligosaccharides. J Infect Dis 153:232-237

29. Willey RL, Smith DH, Lasky LA, Theodore TS, Earl PL, Moss B, Capon DJ, Martin MA 1988 In vitro mutagenesis identifies a region within the envelope gene of the human immunodeficiency virus that is critical for infectivity. $J$ Virol 62:139-147

30. Capon DJ, Chamow SM, Mordenti J, Marsters SA, Gregory T, Mitsuya H, Bryn RA, Lucas C, Wurm FM, Groopman JE, Broder S, Smith DH 1989 Designing CD4 immunoadhesins for AIDS therapy. Nature 337:525-531

31. Mizukami T, Fuerst TR, Berger EA, Moss B 1988 Binding region for human immunodeficiency virus (HIV) and epitopes for HIV-blocking monoclonal antibodies of the CD4 molecule defined by site-directed mutagenesis. Proc Natl Acad Sci USA 85:9273-9277

32. Nygren A, Bergman T, Matthews T, Jornvall H, Wigzell H 1988 95- and 25 $\mathrm{kDa}$ fragments of the human immunodeficiency virus envelope glycoprotein gp 120 bind to the CD4 receptor. Proc Natl Acad Sci USA 85:6543-6546

33. Landau NR, Warton M, Littman DR 1988 The envelope glycoprotein of the human immunodeficiency virus binds to the immunoglobulin-like domain of CD4. Nature 334:159-162

34. Jameson BA, Rao PE, Kong LI, Hahn BH, Shaw GM, Hood LE, Kent SB 1988 Location and chemical synthesis of a binding site for HIV-1 on the CD4 protein. Science 240:1335-1339

35. McDougal JS, Kennedy MS, Sligh JM, Cort SP, Mawle A, Nicholson JK 1986 Binding of HTLV-III/LAV to T4+ T cells by a complex of the $110 \mathrm{~K}$ viral protein and the T4 molecule. Science 231:382-385

36. Matthews TJ, Weinhold KJ, Lyerly HK, Langlois AJ, Wigzell $\mathrm{H}$, Bolognesi DP 1987 Interaction between the human T-cell lymphotropic virus type $\mathrm{III}_{B}$ envelope glycoprotein gp 120 and the surface antigen CD4: role of carbohydrate in binding and cell fusion. Proc Natl Acad Sci USA 84:5425-5428

37. Geyer H, Holschbach C, Hunsmann G, Schneider J 1988 Carbohydrates of human immunodeficiency virus: structures of oligosaccharides linked to the envelope glycoprotein 120. J Biol Chem 263:11760-11767
38. Fenouillet E, Clerget-Raslain B, Gluckman JC, Guetard D, Montagnier L, Bahraoui E 1989 Role of N-linked glycans in the interaction between the envelope glycoprotein of human immunodeficiency virus and its CD4 cellular receptor. J Exp Med 169:807-822

39. Mizuochi T, Spellman MW, Larkin M, Solomon J, Basa LJ, Feizi T 1988 Carbohydrate structures of the human-immunodeficiency-virus (HIV) recombinant envelope glycoprotein gp 120 produced in Chinese-hamster ovary cells. Biochem J 254:599-603

40. Montefiori DC, Robinson Jr WE, Mitchell WM 1988 Role of protein Nglycosylation in pathogenesis of human immunodeficiency virus type 1. Proc Natl Acad Sci USA 85:9248-9252

41. Sattentau QJ, Dalgleish AG, Weiss RA, Beverley PC 1986 Epitopes of the CD4 antigen and HIV infection. Science 234:1120-1123

42. Peterson A, Seed B 1988 Genetic analysis of monoclonal antibody and HIV binding sites on the human lymphocyte antigen CD4. Cell 54:65-72

43. Barr PJ, Steimer KS, Sabin KA, Parkes D, George-Nascimento C, Stephans JC, Powers MA, Gyenes A, Van Nest GA, Miller ET 1987 Antigenicity and immunogenicity of domains of the human immunodeficiency virus (HIV) envelope polypeptide expressed in the yeast Saccharomyces cerevisiae. Vaccine 5:90-101

44. Deen KC, McDougal JS, Inacker R, Folena-Wasserman G, Arthos J, Rosenberg J, Maddon PJ, Axel R, Sweet RW 1988 A soluble form of CD4 (T4) protein inhibits AIDS virus infection. Nature 331:82-84

45. Gosting LH, McClure J, Dickinson ES, Watanabe SM, Shriver K, Goldstein LC 1987 Monoclonal antibodies to gp110 and gp4l of human immunodeficiency virus. J Clin Microbiol 25:845-848

46. Egge H, Dell A, Von Nicolai H 1983 Fucose containing oligosaccharides from human milk. I. Separation and identification of new constituents. Arch Biochem Biophys 224:235-253

47. Ledeen RW, Yu RK 1978 Methods for isolation and analysis of gangliosides. In: Marks N, Rodnight R (eds) Research Methods in Neurochemistry, Vol 4. Plenum, New York, pp 371-410

48. Vance DE, Sweeley CC 1967 Quantitative determination of the neutral glycosyl ceramides in human blood. J Lipid Res 8:621-630

49. Laemmli UK 1970 Cleavage of structural proteins during the assembly of the head of bacteriophage T4. Nature 227:680-685

50. Glossman H, Neville Jr DM 1971 Glycoproteins of cell surfaces: a comparative study of three different cell surfaces of the rat. J Biol Chem 246:6339-6346

51. Kruskall WH, Wallis WA 1952 Use of ranks in one-criterion variance analysis. J Am Statistical Assoc 47:583-621

52. Baba M, de Clercq E, Schols D, Pauwels R, Snoeck R, Van Boeckel C, Van Dedem G, Kraaijeveld N, Hobbelen P, Ottenheijm $H$, Den Hollander F 1990 Novel sulfated polysaccharides: dissociation of anti-human immunodeficiency virus activity from antithrombin activity. $J$ Infect Dis 161:208213

53. Zwiebel JA, Bano M, Nexo E, Salomon DS, Kidwell WR 1986 Partial purification of transforming growth factors from human milk. Cancer Res 46:933939

54. Sherman G, Folch-Pi J 1970 Rotatory dispersion and circular dichroism of brain "proteolipid" protein. J Neurochem 17:597-605

55. Cockle SA, Epand RM, Moscarello MA 1978 Resistance of lipophilin, a hydrophobic myelin protein, to denaturation by urea and guanidinium salts. J Biol Chem 253:8019-8026

56. Lees MB 1982 Proteolipids. Scand J Immunol [Suppl] 9:147-166

57. Fox PC, Wolff A, Yeh CK, Atkinson JC, Baum BJ 1988 Saliva inhibits HIV1 infectivity. J Am Dent Assoc 116:635-637 